\title{
Effects of Marinobacter adhaerens HP15 on polymer exudation by Thalassiosira weissflogii at different $\mathrm{N}: P$ ratios
}

\author{
Astrid Gärdes ${ }^{1,4}$, Yannic Ramaye ${ }^{1}$, Hans-Peter Grossart ${ }^{2}$, Uta Passow ${ }^{3}$, \\ Matthias S. Ullrich ${ }^{1, *}$

\begin{abstract}
${ }^{1}$ Jacobs University Bremen, Molecular Life Science Research Center, Campus Ring 1, 28759 Bremen, Germany ${ }^{2}$ Leibniz Institute of Freshwater Ecology and Inland Fisheries, Alte Fischerhuette 2, 16775 Stechlin, Germany

${ }^{3}$ Marine Science Institute, University of California - Santa Barbara, Santa Barbara, California 93106, USA
\end{abstract} \\ ${ }^{4}$ Present address: San Diego State University, Department of Chemistry and Biochemistry, 5500 Campanile Drive, San Diego, \\ California 92182, USA
}

ABSTRACT: In the ocean, exopolymer accumulation and the resulting aggregation of marine phytoplankton drive the flux of sinking organic matter. Little is known about the contribution of bacteria to the release and build-up of such exudates. We describe an in-depth investigation of exopolymer production under differing nutrient conditions using a diatom-bacteria model system. Responses of the marine diatom Thalassiosira weissflogii to different nutrient regimes and the impact of the co-incubated bacterium Marinobacter adhaerens on algal exudation were evaluated by analyzing quantity and quality of exudation products. Cultures of T. weissflogii were grown at nutrient-balanced conditions (Redfield ratio $\mathrm{N}: \mathrm{P}=16$ ) as well as at nitrogen- or phosphorus-depleted conditions ( $\mathrm{N}: \mathrm{P}=1$ and $\mathrm{N}: \mathrm{P}=95$, respectively) in the presence or absence of $M$. adhaerens. The impact of $M$. adhaerens on the concentration of dissolved organic carbon and transparent exopolymer particles (TEP), as well as on the composition of amino acids and carbohydrates, depended on the nutrient regime. Under nutrient-balanced conditions, $M$. adhaerens stimulated both $T$. weissflogii growth and TEP production. Under nutrient-depleted conditions, TEP production was enhanced regardless of whether bacteria were present. Phosphorus limitation resulted in an appreciable change in the \%mol composition of dissolved amino acids in xenic and axenic treatments. Differential lectin staining revealed that the presence of $M$. adhaerens enhanced and modified the production of specific extracellular substances. A better understanding of the effects of diatom-bacteria interactions on the accumulation of exudation products is crucial in modelling and predicting consequences of environmental changes on oceanic organic matter and nutrient cycling.

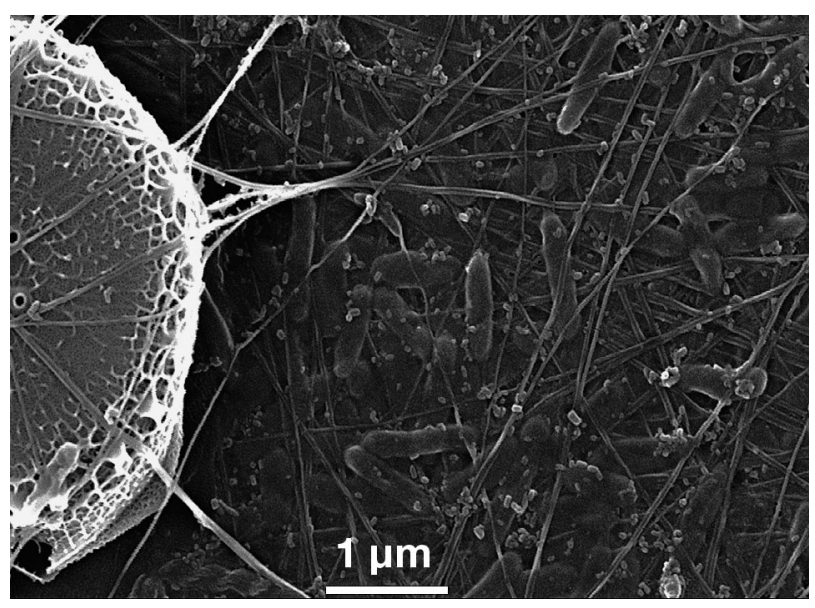

Scanning electron micrograph of a co-incubation sample containing the diatom Thalassiosira weissflogii (left) and Marinobacter adhaerens HP15 embedded in a network of chitincontaining fibres extruding from the diatom cell.

Image: A. Gärdes

KEY WORDS: Diatom-bacteria interactions · Transparent exopolymer particles · TEP · Dissolved organic carbon · Nutrient limitation · Lectin staining · Marinobacter adhaerens $\cdot$ Thalassiosira weissflogii

Resale or republication not permitted without written consent of the publisher

\section{INTRODUCTION}

Certain diatom species are known to release large amounts of dissolved organic carbon (DOC), mostly as carbohydrates and other exopolymeric substances (EPS) into the surrounding seawater (Stal 2003). Once released from the cell surface, cell-bound EPS 
and EPS fibrils (Laspidou \& Rittmann 2002) can form nano-gels (Chin et al. 1998) and transparent exopolymer particles (TEP) (Passow \& Alldredge 1994a, Passow 2000). TEP, which are rich in acidic polysaccharides and are retained as Alcian Blue-stainable particles on filters (Alldredge et al. 1993), promote aggregation by providing the matrix or 'glue' of micro- and macro-aggregates (Alldredge et al. 1993, Logan et al. 1995, Passow 2002a). Aggregates contribute significantly to the sinking flux of carbon out of the euphotic zone (Fowler \& Knauer 1986). It is thus essential to understand conditions that lead to the accumulation of EPS.

Production of exudates by marine phytoplankton is known to be highly variable depending on species, growth stage, and environmental conditions (Myklestad 1974, 1977). Nitrogen depletion, and for some species, phosphorus depletion, can result in an increased extra-cellular release of photosynthesis products by cultured diatoms (Obernosterer \& Herndl 1995, Magaletti et al. 2004, Pierre et al. 2012).

Heterotrophic bacteria interact with phytoplankton in the so-called 'phycosphere,' which is the microzone surrounding algal cells (Bell \& Mitchell 1972). The type of interaction, e.g. competition or mutualism, often depends on nutrient availability (Grossart 1999, Lovdal et al. 2008). Thus, depending on the type of interaction, diatom-associated bacteria may have the potential to impact the release of algal exudates (Bruckner et al. 2011), TEP formation (Bhaskar et al. 2005, Grossart et al. 2006), aggregation (Gärdes et al. 2011), and sedimentation (Smith et al. 1995). On the one hand, heterotrophic bacteria cause hydrolysis of algal products (Bidle \& Azam 1999, Grossart et al. 2007, Sapp et al. 2008) resulting in reduced EPS accumulation. On the other hand, EPS including TEP are colonized, formed, utilized, and modified by bacteria (Passow \& Alldredge 1994b, Mari \& Kiørboe 1996, Verdugo et al. 2004), providing bacterial niches as well as substrates (Azam \& Malfatti 2007). Phytoplankton exudation may have evolved as a mechanism to establish mutualism between heterotrophic bacteria and phytoplankton, in particular by attracting bacteria as EPS re-mineralizers (Azam \& Cho 1987).

The role that bacteria-diatom interactions play with regards to the production of exopolymers and the impact of nutrient availability in determining these interactions are largely unknown. Here, we present a series of in vitro experiments using the marine diatom Thalassiosira weissflogii and the bacterium Marinobacter adhaerens HP15 (hereafter Marinobacter adhaerens) as a model to investigate nutrient-dependent exopolymer production by dia- toms in the presence or absence of diatom-associated bacteria. $M$. adhaerens, which was isolated from marine aggregates (Grossart et al. 2004), preferentially attaches to the surface of $T$. weissflogii and specifically contributes to TEP formation and algal aggregation (Gärdes et al. 2011). The bacterium has been taxonomically characterized (Kaeppel et al. 2012); its genome sequence has been fully annotated (Gärdes et al. 2010), and its genetic accessibility has been demonstrated (Sonnenschein et al. 2011), rendering it a suitable model organism. To evaluate the response of $T$. weissflogii to different nutrient conditions and the concurrent impact of $M$. adhaerens on polymer exudation, the dynamics of DOC and TEP, as well as the composition and amount of released polysaccharides and amino acids, were measured. We hypothesized that $M$. adhaerens affects quantity and quality of the released algal exudates in a nutrient-dependent manner.

\section{MATERIALS AND METHODS}

\section{Diatom batch cultures, bacteria, and experimental setup}

Axenic Thalassiosira weissflogii (CCMP 1336) was obtained from the Provasoli-Guillard National Center for Culture of Marine Phytoplankton (CCMP, Maine, USA) and routinely grown in sterile autoclaved pre-filtered f/2 medium (Guillard 1975) based on artificial seawater (ASW) in $150 \mathrm{ml}$ cell culture flasks. The cultures were checked regularly for bacterial contamination by microscopic observation and agar plating on marine broth (MB; ZoBell 1941). Diatom cells were quantified by cell counting as described below.

Five liters of axenic diatom cultures were grown at $16^{\circ} \mathrm{C}$ in $\mathrm{f} / 2$ medium using a $12 \mathrm{~h}$ light period at $150 \mu \mathrm{mol}$ photons $\mathrm{m}^{-2} \mathrm{~s}^{-1}$ for $9 \mathrm{~d}$. Thalassiosira weissflogii cells were harvested by centrifugation $(4139 \times g$, $10 \mathrm{~min}$ ) and subsequently washed with sterile ASW to minimize nutrient carry-over. Aliquots of approximately $5000 \mathrm{~T}$. weissflogii cells were used to inoculate 6 of 7 experimental treatments $(600 \mathrm{ml}$ medium in 11 cell culture flasks). The control treatment did not contain diatoms. The experimental setup is outlined in Fig. 1. Macro-nutrients in the medium were adjusted as follows. In treatments I and II, which were designated as 'nutrient-balanced,' nutrients were adjusted to $580 \mu \mathrm{M}$ silicate, $425 \mu \mathrm{M}$ nitrogen, and $26 \mu \mathrm{M}$ phosphorus ( $\mathrm{N}: \mathrm{P}=16)$. In the medium for treatments III and IV, nitrogen $(26 \mu \mathrm{M})$ was reduced 
Fig. 1. Experimental set-up. Aliquots of an axenic Thalassiosira weissflogii culture were transferred to nutrient-balanced $(\mathrm{N}: \mathrm{P}=16)$ nitrogen-depleted $(\mathrm{N}: \mathrm{P}=1)$, and phosphorusdepleted (N:P = 95) treatments (see 'Materials and methods' for concentration) and incubated without (axenic) or with the bacterium Marinobacter adhaerens HP15 (xenic). As a control, $M$. adhaerens HP15 without diatoms was incubated in nutrient-balanced conditions. Two replicates were used per treatment or control. DOC: dissolved organic carbon; DFAA: dissolved free amino acids; DCAA: dissolved combined amino acids; DFCHO: dissolved free neutral and acidic monosaccharides; DCCHO: dissolved combined neutral and acidic polysaccharides; TEP: transparent exopolymer particles

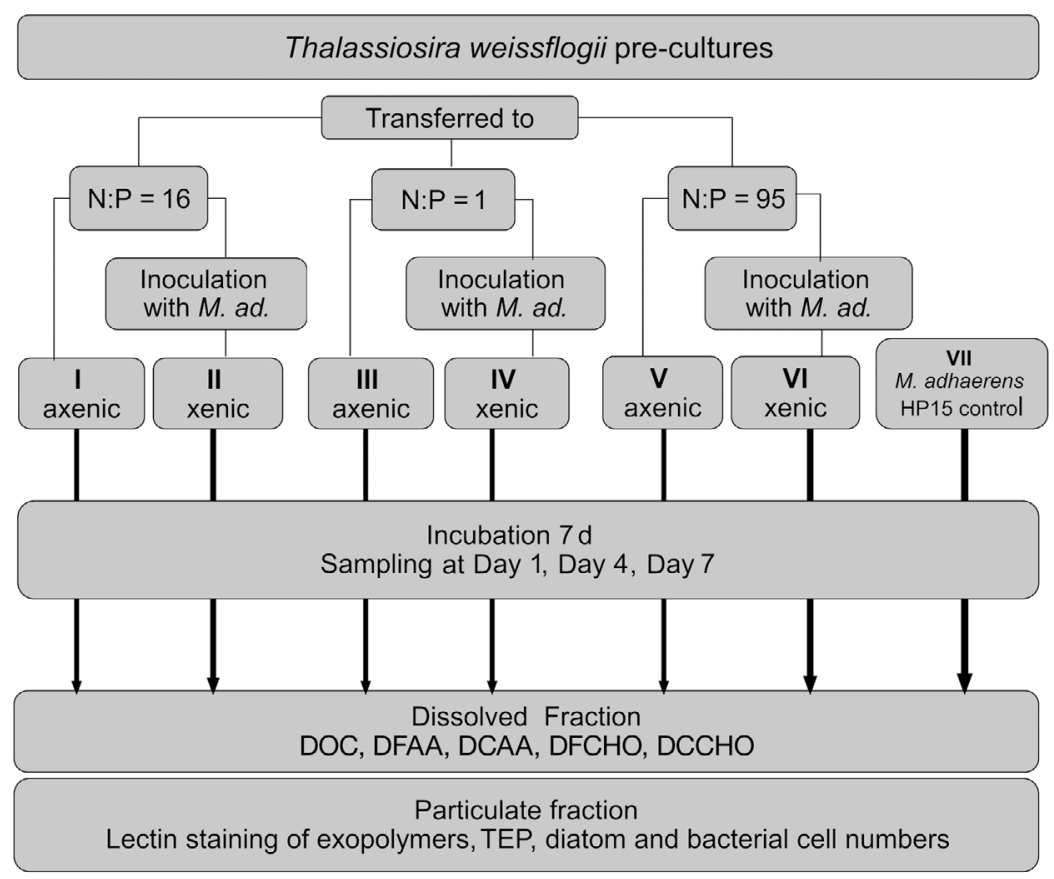

to an N:P ratio of 1 and termed 'nitrogen-depleted' (Table 1). In contrast, treatments V and VI contained medium depleted in phosphate $(4.5 \mu \mathrm{M})$ with an $\mathrm{N}: \mathrm{P}$ ratio of 95 and hence was designated as 'phosphorusdepleted' (Table 1). Treatments I, III, and V were kept axenic, whereas the bacterial strain Marinobacter adhaerens was added to treatments II, IV, and VI (xenic treatments). Control treatment VII contained nutrient-balanced medium without diatoms but with $M$. adhaerens. The bacterium was routinely grown in MB (ZoBell 1941) in $100 \mathrm{ml}$ Erlenmeyer flasks shaken at $150 \mathrm{rpm}$ at $18^{\circ} \mathrm{C}$. To avoid carry-over of MB and bacterial metabolites, $M$. adhaerens cells were washed and incubated overnight in ASW (Grossart $1999)$ at $18^{\circ} \mathrm{C}$. Thereafter, $1 \mathrm{ml}$ of the bacterial suspension was added to the respective treatments to give a final density of $\sim 3 \times 10^{6}$ cells $\mathrm{ml}^{-1}$.

All treatments were incubated at $16^{\circ} \mathrm{C}$ using a $12 \mathrm{~h}$ light period at $150 \mu \mathrm{mol}$ photons $\mathrm{m}^{-2} \mathrm{~s}^{-1}$ for $7 \mathrm{~d}$. Subsamples of $20 \mathrm{ml}$ were taken with sterile syringes on Days 0,4 , and 7 and subjected to microbial and biochemical analyses.

\section{Determination of diatom and bacterial cell concentrations}

Cell concentrations of diatoms were determined by cell counts in a Sedgwick-Rafter Cell S50 (SPI Supplies) using an inverted Axiovert 200 microscope (Zeiss). Bacterial cell numbers in the initial inocula were determined by serial dilution plating and throughout the experiment by microscopic enumerations of 4',6-diamino-2-phenylindole (DAPI)-stained bacteria. In preparation for the DAPI counts, $200 \mu \mathrm{l}$ samples were diluted $1: 2$ and $1: 10$ in sterile $f / 2$ medium, fixed with $0.2 \mu \mathrm{m}$ pore size pre-filtered, borate-buffered $2 \%$ formalin, and stained with DAPI $\left(1 \mathrm{\mu g} \mathrm{ml}^{-1}\right)$ for $3 \mathrm{~min}$ (Porter \& Feig 1980). Samples were filtered onto $0.2 \mu \mathrm{m}$ pore size polycarbonate Nucleopore filters (Whatman) and stored at $-20^{\circ} \mathrm{C}$. Bacterial cell numbers were counted in replicates using an epifluorescence Axioplan microscope (Zeiss) at $1000 \times$ magnification.

\section{Nutrient analysis}

Concentrations of $\mathrm{NO}_{3}{ }^{-}$and $\mathrm{PO}_{4}{ }^{-}$were determined spectrophotometrically at all 3 sampling points using an Auto Analyzer Evolution III apparatus (Alliance Instruments). Ten $\mathrm{ml}$ samples were pre-filtered $(0.2$ $\mu \mathrm{m}$ Nucleopore) and kept at $-20^{\circ} \mathrm{C}$ until analysis. Determination of nutrients was performed in duplicates according to an established method (Strickland \& Parsons 1972).

\section{Dissolved organic carbon (DOC)}

For DOC analysis, replicates of $10 \mathrm{ml}$ samples were collected in pre-combusted glass ampoules 
Table 1. Concentrations of $\mathrm{NO}_{3}{ }^{-}$and $\mathrm{PO}_{4}{ }^{3-}$ in the different treatments and control after 1, 4, and $7 \mathrm{~d}$. Data are mean \pm $\mathrm{SD}$ of replicates

\begin{tabular}{|c|c|c|c|c|}
\hline Treatment & & $\begin{array}{c}\text { Incubation } \\
\text { day }\end{array}$ & $\begin{array}{l}\mathrm{NO}_{3}^{-} \\
(\mu \mathrm{m})\end{array}$ & $\begin{array}{c}\mathrm{PO}_{4}{ }^{3-} \\
(\mu \mathrm{m})\end{array}$ \\
\hline \multicolumn{5}{|c|}{ Balanced nutrient conditions } \\
\hline \multirow[t]{6}{*}{$(\mathrm{N}: \mathrm{P}=16)$} & Axenic & 1 & $424 \pm 26$ & $25.1 \pm 6$ \\
\hline & & 4 & $358 \pm 11$ & $8.35 \pm 2.5$ \\
\hline & & 7 & $341 \pm 16$ & $4.35 \pm 2.7$ \\
\hline & Xenic & 1 & $439 \pm 41$ & $26.1 \pm 7.6$ \\
\hline & & 4 & $385 \pm 9$ & $7.5 \pm 2$ \\
\hline & & 7 & $366 \pm 37$ & $3.9 \pm 1.1$ \\
\hline \multicolumn{5}{|c|}{ Nitrogen-depleted conditions } \\
\hline \multirow[t]{6}{*}{$(\mathrm{N}: \mathrm{P}=1)$} & Axenic & 1 & $26.3 \pm 1.8$ & $29 \pm 8.5$ \\
\hline & & 4 & $0.55 \pm 0.06$ & $23 \pm 6$ \\
\hline & & 7 & $0.7 \pm 0.1$ & $23 \pm 9.9$ \\
\hline & Xenic & 1 & $24.8 \pm 2.2$ & $27 \pm 4.5$ \\
\hline & & 4 & $0.42 \pm 0.09$ & $25 \pm 5.8$ \\
\hline & & 7 & $0.69 \pm 0.1$ & $24 \pm 6.1$ \\
\hline \multicolumn{5}{|c|}{ Phosphorus-depleted conditions } \\
\hline \multirow[t]{6}{*}{$(\mathrm{N}: \mathrm{P}=95)$} & Axenic & 1 & $464 \pm 22$ & $4.8 \pm 0.9$ \\
\hline & & 4 & $414.8 \pm 27$ & $0.51 \pm 0.1$ \\
\hline & & 7 & $404.8 \pm 15$ & $0.18 \pm 0.1$ \\
\hline & Xenic & 1 & $410.4 \pm 10$ & $5.57 \pm 1$ \\
\hline & & 4 & $368 \pm 25$ & $2.25 \pm 0.6$ \\
\hline & & 7 & $370 \pm 31$ & $1.98 \pm 0.9$ \\
\hline \multirow[t]{3}{*}{$\mathrm{N}: \mathrm{P}=16$} & Control & 1 & $466 \pm 37$ & $26 \pm 4.2$ \\
\hline & & 4 & $425 \pm 21$ & $15.5 \pm 1.2$ \\
\hline & & 7 & $370 \pm 26$ & $10.9 \pm 3.3$ \\
\hline
\end{tabular}

(Carl Roth) after filtration through pre-rinsed $0.2 \mu \mathrm{m}$ polycarbonate membranes (Nucleopore). Samples were acidified with $1 \%$ phosphoric acid, flamesealed, and stored at $-20^{\circ} \mathrm{C}$ (Grossart et al. 2006). DOC analysis was performed using a high-temperature catalytic combustion TOC-5000 instrument (Shimadzu). Given DOC concentrations are averages of 3 injections from each sample and sampling point.

\section{Amino acids}

Ten ml samples from each sampling point (Days 0, 4 , and 7), were filtered through $0.2 \mu \mathrm{m}$ pore size lowprotein binding Acrodisc syringe $0.2 \mu \mathrm{m}$ filters with HT Tuffryn ${ }^{\circledR}$ membrane (Sigma-Aldrich) and stored at $-20^{\circ} \mathrm{C}$ until analysis. Concentrations of dissolved free amino acids (DFAA) were analyzed by HPLC after pre-column derivatization with ortho-phthaldialdehyde (Mopper et al. 1992). Dissolved combined amino acids (DCAA) were hydrolyzed with $6 \mathrm{~N} \mathrm{HCl}$ at $155^{\circ} \mathrm{C}$ for $1 \mathrm{~h}$ and analyzed as DFAA (Rosenstock \& Simon 1993).

\section{Carbohydrates}

Ten ml samples from each sampling point (Days 0, 4 , and 7) were filtered through $0.2 \mu \mathrm{m}$ pore size polycarbonate filters (Nucleopore) and stored at $-20^{\circ} \mathrm{C}$ in $15 \mathrm{ml}$ sterile falcon tubes. Dissolved free neutral and acidic monosaccharides (DFCHO) were analyzed by HPLC (Dionex) with a Carbopac PA 10 column (Dionex) and pulsed amperometric detection, using a gradient of 3 eluents (10 mM NaOH, $250 \mathrm{mM} \mathrm{NaOH}$, and $25 \mathrm{mM} \mathrm{NaOH}+1 \mathrm{M} \mathrm{Na}$-acetate buffer) according to the manufacturer's protocol. Dissolved combined neutral and acidic polysaccharides (DCCHO) were analyzed by HPLC as DFCHO after $20 \mathrm{~h}$ of hydrolysis with $0.09 \mathrm{~N} \mathrm{HCl}$ at $100^{\circ} \mathrm{C}$ (Mopper et al. 1992).

\section{Transparent exopolymer particles (TEP)}

For quantitative TEP analysis, replicate samples of 2 to $5 \mathrm{ml}$ from each sampling point (Days 0, 4, and 7) were filtered onto $0.2 \mu \mathrm{m}$ pore size polycarbonate membranes, which were subsequently stained with Alcian blue (8GX, final concentration $0.05 \%$ in $\mathrm{Na}-$ acetate buffer at pH 5.8; Alldredge et al. 1993). Filters were dried and placed on Cytoclear TM slides (Poretics). Twenty randomly selected grids were examined by light microscopy at $200 \times$ magnification. Image Analysis V 3.0 software (Soft Imaging System) was used to enumerate TEP in size classes, determining total area and size distribution. In total, 300 to 700 TEP per slide were measured. The majority of TEP observed were small, ovate particles. TEP were grouped into geometric size classes based on maximal length. The maximal and minimum length axes were used to calculate the elliptical area of TEP in each size class. The size spectrum from 20 grids and the average size in each size class were used to calculate the total area of TEP, which is a proxy for biomass (Passow 2002a). TEP size frequency distribution was calculated after $7 \mathrm{~d}$.

\section{Lectin staining}

Two lectins were used to test for their binding to specific diatom-derived extracellular polymers: concanavalin A-fluorescein isothiocyanate (FITC-ConA; Sigma), specific for glucose and mannose residues, and Bandeiraea simplicifolia lectin-tetramethyl rhodamine isothiocyanate (TRITC-Bandeiraea, Sigma), specific for galactose and $N$-acetylgalactose residues. 
Both lectins were applied according to Liener et al. (1986) with modifications as published by Wigglesworth-Cooksey \& Cooksey (2005) at the initial (Day 0) and final sample points (Day 7) in sterile 8-well cover slip chambers (Ibidi). Two hundred $\mu \mathrm{l}$ per sample were stained with lectin concentrations of $0.1 \mathrm{mg} \mathrm{ml}^{-1}$ in $\mathrm{f} / 4$ medium and incubated for 1 to $2 \mathrm{~h}$ in darkness. Unbound lectins were removed by adding $100 \mu \mathrm{l}$ of bovine serum albumin (BSA; $1 \%$ in phosphate-buffered saline buffer). In all unstained controls, lectin solutions were replaced by BSA. FITC-ConA and TRITC-Bandeiraea binding activities were determined by confocal laser scanning microscopy (CLSM) using an Axiovert 400 (Zeiss) with 1 argon and 1 krypton laser (excitation wave lengths of 488 and $568 \mathrm{~nm}$, respectively, and emission wave lengths of 350 and $560 \mathrm{~nm}$, respectively). Autofluorescence of chlorophyll a was detected using an excitation wave length of $488 \mathrm{~nm}$ and an emission wave length of $655 \mathrm{~nm}$. Images were processed using the Zeiss LSM Image Browser.

\section{Statistical analyses}

Simple regression analysis was carried out to assess the relationships between measured parameters. One-way analysis of variance (ANOVA) was used to assess the differences between DOC, DFAA, DCAA, DFCHO, DCCHO, and TEP, as well as algal and bacterial cell numbers in xenic and axenic treatments and between balanced and depleted treatments.

\section{RESULTS}

\section{Nutrient concentrations}

At the end of the experiment, after $7 \mathrm{~d}$, nitrogen concentrations were lower under axenic nutrient-balanced conditions as compared to the respective xenic treatment, indicating either a decreased nitrogen uptake by Thalassiosira weissflogii or an additional supply of nitrogen by bacterial remineralization (Table 1). At this time, nitrogen concentrations were low in both axenic and xenic treatments under nitrogen-depleted conditions. Under phosphorus-depleted conditions, axenic treatments had used up all available phosphorus, whereas in xenic treatments, final phosphorus concentrations were $2 \mu \mathrm{M}$ (Table 1 ). In the control treatment, nitrogen concentration decreased almost as much as in the diatom-containing treatment, but phosphorus concentrations decreased less.

\section{Phytoplankton and bacterial abundances}

Thalassiosira weissflogii cell numbers increased exponentially over the entire $7 \mathrm{~d}$ of incubation in both axenic and xenic nutrient-balanced treatments (Fig. 2A). The increase in algal cell numbers was largest in xenic cultures between Days 4 and 7 (from $1.6 \times 10^{4} \pm 3.2 \times 10^{2}$ [SD] cells $\mathrm{ml}^{-1}$ to $4.7 \times$ $10^{4} \pm 6.8 \times 10^{2}$ cells $\mathrm{ml}^{-1}$ ). Moreover, in nutrientbalanced treatments, final diatom numbers were significantly higher ( $\mathrm{p}<0.05, \mathrm{n}=6$ ) when Marinobacter adhaerens cells were present. In these treatments, bacterial cell numbers increased rapidly, reaching $8.8 \pm 1.1 \times 10^{6}$ cells $\mathrm{ml}^{-1}$ within $4 \mathrm{~d}$ and remaining nearly constant thereafter (Fig. 3).

In contrast, in nitrogen- as well as in phosphorusdepleted conditions ( $\mathrm{N}: \mathrm{P}=1$ and $\mathrm{N}: \mathrm{P}=95$, respectively), diatom growth was significantly lower $(\mathrm{p}<0.05, \mathrm{n}=6)$ than in nutrient-balanced treatments. Diatom cell numbers increased from $5 \times 10^{3} \pm 0.42 \times 10^{3}$ cells $\mathrm{ml}^{-1}$ to only $2.1 \times 10^{4} \pm 3.3 \times 10^{3}$ cells ml ${ }^{-1}$ unaffected by the presence of Marinobacter adhaerens under nutrient deprivation (Fig. 2B,C). In nitrogen- and phosphorus-depleted treatments, $M$. adhaerens cell numbers reached a final concentration of $6.3 \pm 0.9 \times$ $10^{6}$ cells ml ${ }^{-1}$ and $5.9 \pm 2.1 \times 10^{6}$ cells ml $^{-1}$, respectively (Fig. 3), both significantly lower than under nutrientbalanced conditions ( $\mathrm{p}<0.05, \mathrm{n}=6)$.

In the bacterial control treatments, however, bacterial abundances decreased by 2 orders of magnitude from initially $3.3 \pm 1.0 \times 10^{6}$ cells ml ${ }^{-1}$ to $3.8 \pm 0.8 \times 10^{4}$ cells $\mathrm{ml}^{-1}$ at the end of the incubation, indicating that bacteria lacked a suitable carbon source such as algal exudates.

\section{Dynamics of dissolved organic matter}

In nutrient-balanced treatments, DOC concentrations differed significantly $(\mathrm{p}<0.05)$ between axenic and xenic treatments (Fig. 4A). Higher DOC concentrations occurred when diatom cells grew without bacteria (axenic): initial DOC concentrations increased from $150 \pm 17.1 \mu \mathrm{M} \mathrm{C}$ to $600 \pm 43.2 \mu \mathrm{M} \mathrm{C}$ on the fourth day of the incubation and remained high thereafter. In contrast, DOC concentrations increased to only $400 \pm 12.8 \mu \mathrm{M} \mathrm{C}$ in xenic nutrientbalanced treatments (Fig. 4A), suggesting that bacteria took up substantial amounts of DOC. In the nitrogen-depleted treatment, however, no differences in DOC concentrations between axenic and xenic cultures were observed, and DOC concentrations declined to $107 \pm 20.9 \mu \mathrm{M} \mathrm{C}$ irrespective of the 

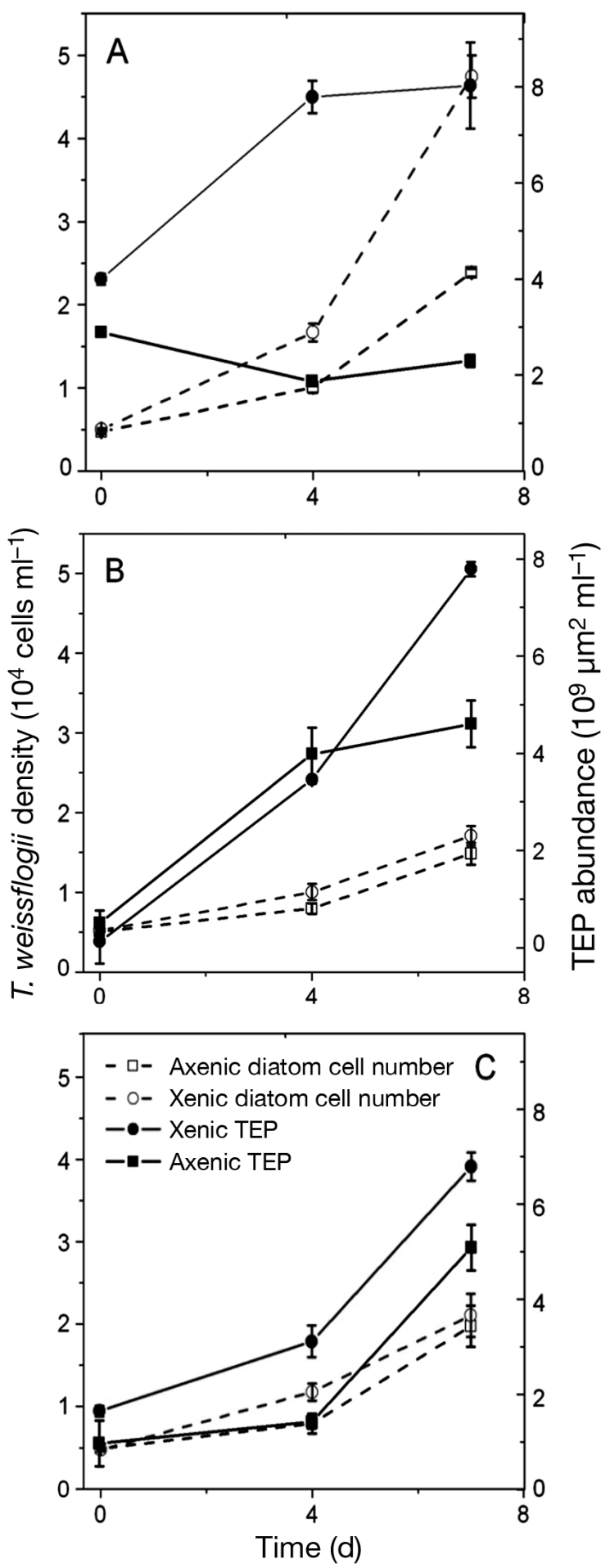

Fig. 2. Total proxy of abundance of transparent exopolymer particles (TEP; filled symbols) and cell density of Thalassiosira weissflogii (empty symbols) grown under (A) nutrientbalanced $(\mathrm{N}: \mathrm{P}=16)$, $(\mathrm{B})$ nitrogen-depleted $(\mathrm{N}: \mathrm{P}=1)$, and $(\mathrm{C})$ phosphorus-depleted treatments $(\mathrm{N}: \mathrm{P}=95)$ without (axenic; squares) or with Marinobacter adhaerens HP15 (xenic; circles). Values are means between replicates with SD as error bars. SDs are smaller than the symbol in some cases

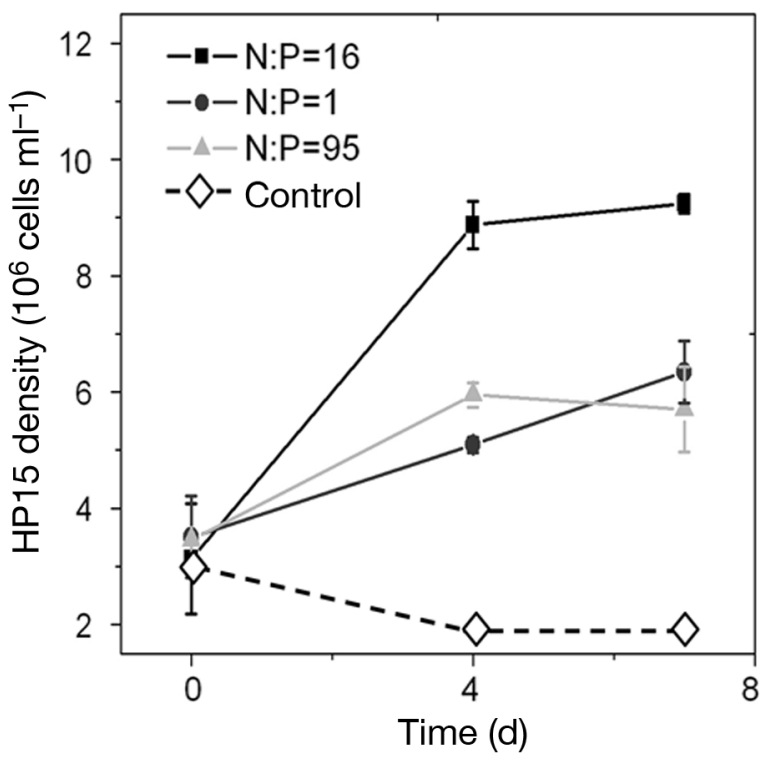

Fig. 3. Marinobacter adhaerens HP15. Cell density (mean \pm $\mathrm{SD}$ of 3 replicates) in the 3 xenic treatments, as well as in the bacteria-only control

presence of bacteria (Fig. 4B). In the phosphorusdepleted treatment, high DOC concentrations were measured (average $=470.5 \pm 31.2 \mu \mathrm{M} \mathrm{C}$ ) regardless of bacterial presence, and DOC remained constant over time (Fig. 4C). The 1-way ANOVA revealed that DOC concentration over time differed significantly only between axenic and xenic treatments under nutrient-balanced conditions, and showed a significant difference between nutrient-balanced and depleted conditions only in the xenic treatments (Table 2). This suggested that bacterial DOC utilization depended on nutrient availability and was highest under nutrient-balanced conditions.

Concentrations of DFCHO were below $0.25 \mu \mathrm{mol}$ $\mathrm{I}^{-1}$ at all sampling points and did not differ among the different nutrient treatments or axenic and xenic cultures. Hydrolysis and HPLC analyses revealed glucose as the most abundant monomer in all exudates (data not shown).

DCCHO concentrations were below $0.1 \mu \mathrm{mol} \mathrm{l}^{-1}$ in both nutrient-balanced and phosphorus-depleted treatments, both in the presence or absence of bacteria. In nitrogen-depleted treatments, DCCHO were 3.8 and $2.1 \mu \mathrm{mol} \mathrm{l}^{-1}$ in axenic and xenic cultures, with glucose accounting for 65 and $45 \%$ (2.5 and $0.95 \mathrm{~mol} \mathrm{l}^{-1}$ ), respectively. Other monosaccharides in the DCCHO pool included fucose, ribose, rhamnose, arabinose, galactose, and mannose (data not shown). The 1-way ANOVA revealed no significant differences in final DFCHO concentrations between most treatments, but DCCHO significantly $(\mathrm{p}<0.05)$ dif- 
Table 2. p-values of 1-way ANOVA testing for significant differences between axenic and xenic treatments and between nutrient regimes on Day 7. DOC: dissolved organic carbon; DFAA: dissolved free amino acids; DCAA: dissolved combined amino acids; DFCHO: dissolved free neutral and acidic monosaccharides; DCCHO: dissolved combined neutral and acidic polysaccharides; TEP: transparent polymer particles; NS: not significant; (-) not applicable

\begin{tabular}{|c|c|c|c|c|c|}
\hline & \multicolumn{3}{|c|}{$\begin{array}{l}\text { Axenic vs. xenic } \\
\text { treatments }\end{array}$} & \multicolumn{2}{|c|}{$\begin{array}{c}\text { Balanced vs. } \\
\text { nutrient-depletec }\end{array}$} \\
\hline & $\mathrm{N}: \mathrm{P}=16$ & $\mathrm{~N}: \mathrm{P}=95$ & $\mathrm{~N}: \mathrm{P}=1$ & Axenic & Xenic \\
\hline $\mathrm{DOC}\left(\mu \mathrm{mol} \mathrm{C} \mathrm{l}^{-1}\right)$ & 0.024 & NS & NS & NS & 0.032 \\
\hline DFAA $\left(\mu \mathrm{mol} \mathrm{l} \mathrm{l}^{-1}\right)$ & NS & NS & NS & 0.007 & 0.001 \\
\hline DCAA $\left(\mu \mathrm{mol} \mathrm{l}{ }^{-1}\right)$ & 0.033 & NS & NS & NS & 0.05 \\
\hline DFAA \%mol composition & NS & NS & NS & NS & NS \\
\hline DCAA \%mol composition & NS & NS & 0.0009 & 0.039 & 0.042 \\
\hline DFCHO $\left(\mu \mathrm{mol} \mathrm{l}^{-1}\right)^{+}$ & NS & NS & NS & & \\
\hline DCCHO $\left(\mu \mathrm{mol} \mathrm{l}^{-1}\right)$ & NS & 0.033 & NS & NS & NS \\
\hline $\operatorname{TEP}\left(\mu \mathrm{m}^{2} \mathrm{ml}^{-1}\right)$ & 0.046 & NS & NS & 0.089 & NS \\
\hline TEP size frequency distribution & 0.044 & NS & NS & 0.009 & NS \\
\hline Diatoms (cells ml ${ }^{-1}$ ) & 0.01 & NS & NS & NS & 0.036 \\
\hline Bacteria (cells ml ${ }^{-1}$ ) & - & - & - & - & 0.048 \\
\hline
\end{tabular}

tions of up to $3.3 \mu \mathrm{mol} \mathrm{l}^{-1}$. In xenic cultures, higher DCAA concentrations were observed, with peak values of $4.2 \mu \mathrm{mol} \mathrm{l}^{-1}$ on Day 4 (Fig. 5A). In axenic, nitrogendepleted treatments, DCAA concentrations peaked on Day 4 $\left(3.6 \mu \mathrm{mol} \mathrm{l}^{-1}\right)$. In the corresponding xenic treatment, DCAA decreased moderately from 3.5 to $3 \mu \mathrm{mol} \mathrm{l}^{-1}$ (Fig. 5B). In axenic, phosphorus-depleted treatments, DCAA increased to $3.9 \mu \mathrm{mol} \mathrm{l}^{-1}$. In contrast, nearly constant concentrations of ca. $2 \mu \mathrm{mol} \mathrm{l^{-1 }}$ were observed in the xenic, phosphorus-depleted treatments (Fig. 5C). DCAA concentrations differed significantly between xenic nutrient-balanced and nutrient-

fered between axenic and xenic cultures in nitrogendepleted treatments (Table 2). This suggested that presence of $M$. adhaerens may lead to lower DCCHO concentrations when nitrogen availability is low.

Concentrations of DFAA and DCAA were measured in 1 of the duplicate treatments. DFAA concentrations in the nutrient-balanced treatments increased in both axenic and xenic cultures, from 0.4 to $0.62 \mu \mathrm{mol} \mathrm{l}^{-1}$ and from 0.1 to $0.68 \mu \mathrm{mol} \mathrm{l}^{-1}$, respectively (Fig. 5A). In nitrogen-depleted treatments, DFAA concentrations on Day 7 were substantially lower $\left(\leq 0.06 \mu \mathrm{mol} \mathrm{l}^{-1}\right)$ in the axenic treatment than in the xenic one. In the xenic treatment, DFAA first increased to $0.87 \mu \mathrm{mol} \mathrm{l}^{-1}$ on Day 4, and then declined to $0.44 \mu \mathrm{mol} \mathrm{l}^{-1}$ at the end of the experiment (Fig. 5B). Maximum DFAA concentrations were observed in the phosphorus-depleted xenic $(1.9 \mu \mathrm{mol}$ $\left.\mathrm{l}^{-1}\right)$ and axenic $\left(1.4 \mu \mathrm{mol}^{-1}\right)$ treatments (Fig. 5C). The 1-way ANOVA revealed that in nitrogen- and phosphorus-depleted treatments, significantly higher DFAA concentrations were measured compared to nutrient-balanced conditions in both axenic ( $\mathrm{p}<$ $0.001)$ and xenic $(\mathrm{p}<0.001)$ treatments (Table 2$)$, but it showed no difference between xenic and axenic treatments.

The average mol-composition (mol\%) of DFAA in all treatments, irrespective of inorganic nutrients or bacterial presence, remained similar over time. Aspartate, glutamate, tyrosine, and serine represented $8-2.5,10-14.5,4-10$, and $38-45 \%$ of DFAA, respectively (data not shown).

Under nutrient-balanced conditions, DCAA in axenic cultures increased and reached concentra- depleted treatments ( $p<0.05$; Table 2). Axenic treatments differed significantly from xenic treatments when nutrients were balanced ( $p<0.05$; Table 2$)$.

Final DCAA composition in both axenic and xenic treatments under nutrient-balanced or nitrogendepleted conditions were characterized by highest mol\% of alanine (22 to $29 \%$ and 33 to $27 \%$, respectively) and glycine (12 to $16 \%$ and 12 to $15 \%$, respectively; Fig. 6). In phosphorus-depleted treatments, phenylalanine and leucine comprised the highest $\mathrm{mol} \%$ values in both axenic and xenic treatments (23 to $27 \%$ for phenylalanine and 23 and $15 \%$ for leucine). Additionally, phosphorus-depleted treatments differed significantly from nutrient-balanced and nitrogen-depleted treatments, respectively, when axenic $(\mathrm{p}<0.05)$ and xenic $(\mathrm{p}<0.05)$ treatments were compared (Table 2). This suggested that changes in quantity and quality of accumulated DCAA were triggered by nutrient availability.

\section{TEP formation}

In nutrient-balanced treatments, final TEP concentrations differed significantly between axenic and xenic treatments ( $p<0.05$; Table 2). No TEP formation was observed in axenic treatments $\left(2.1 \pm 0.2 \times 10^{9} \mu^{2}\right.$

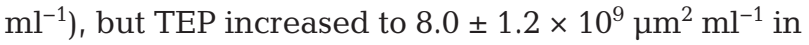
xenic treatments (Fig. 2A). There was no significant difference in TEP accumulation rate between axenic and xenic treatments in any of the nutrient-depleted treatments (Table 2), and the average TEP concentration was $7.5 \pm 1.9 \times 10^{9} \mathrm{~mm}^{2} \mathrm{ml}^{-1}$ (Fig. 2B,C). 

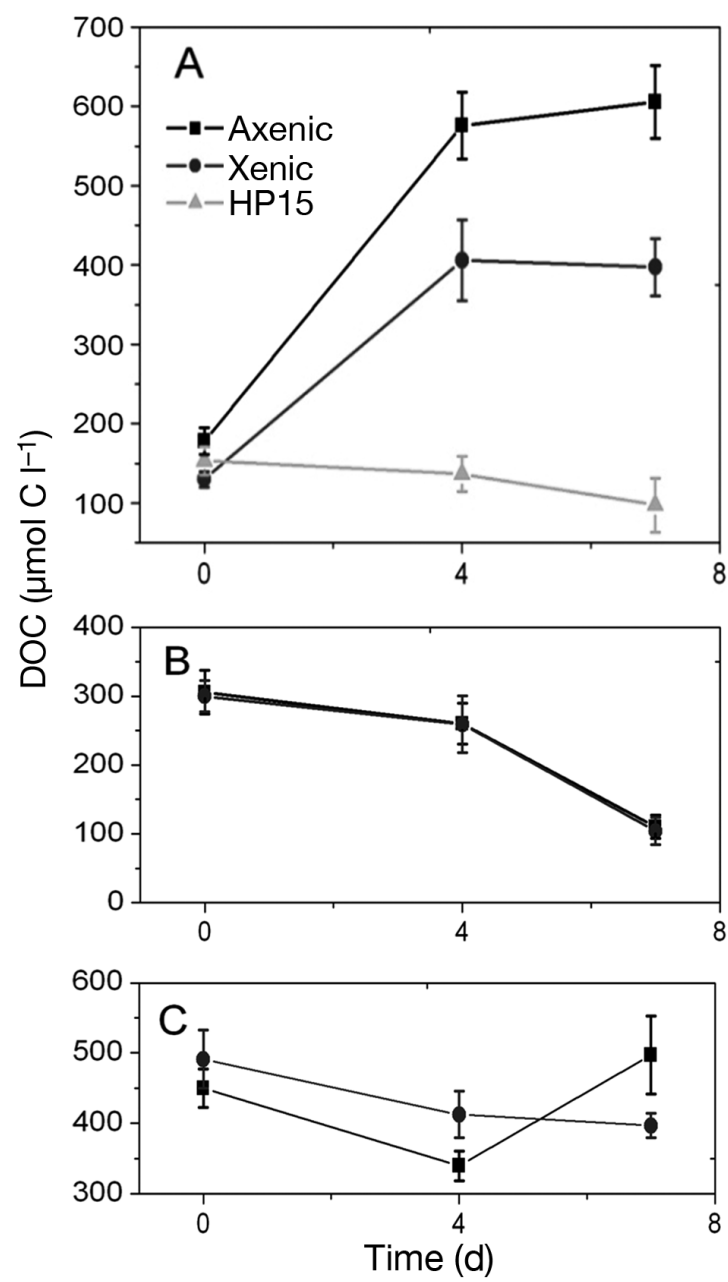

Fig. 4. Concentrations of dissolved organic carbon (DOC) in (A) nutrient-balanced ( $\mathrm{N}: \mathrm{P}=16)$, (B) nitrogen-depleted ( $\mathrm{N}: \mathrm{P}$ $=1)$, or $(C)$ phosphorus-depleted treatments (N:P = 95) without (axenic) or with Marinobacter adhaerens HP15 (xenic). DOC in the bacteria-only control is depicted in panel A (triangles)

After $7 \mathrm{~d}$ under nutrient-balanced conditions, significantly $(p<0.05)$ more TEP occurred in the size class of 200 to $1000 \mu^{2}$ in the xenic than in the axenic treatments, a large fraction of TEP $<200 \mu^{2}$ being observed in the latter class. The proportion of TEP $>1000 \mu^{2}$ was highest in the xenic, nutrientbalanced treatment, contributing almost $8 \%$ of total TEP numbers (Fig. 7). Under nutrient-depleted conditions, the difference between xenic and axenic treatments was less pronounced. All nutrient-depleted treatments revealed major proportions of TEP in the size class between 200 and $1000 \mu^{2}(\mathrm{p}<0.05)$, with size frequency distributions similar to those in the xenic nutrient-balanced treatments. Calculation of TEP production per diatom cell revealed high cellspecific TEP concentrations in xenic, phosphorus-
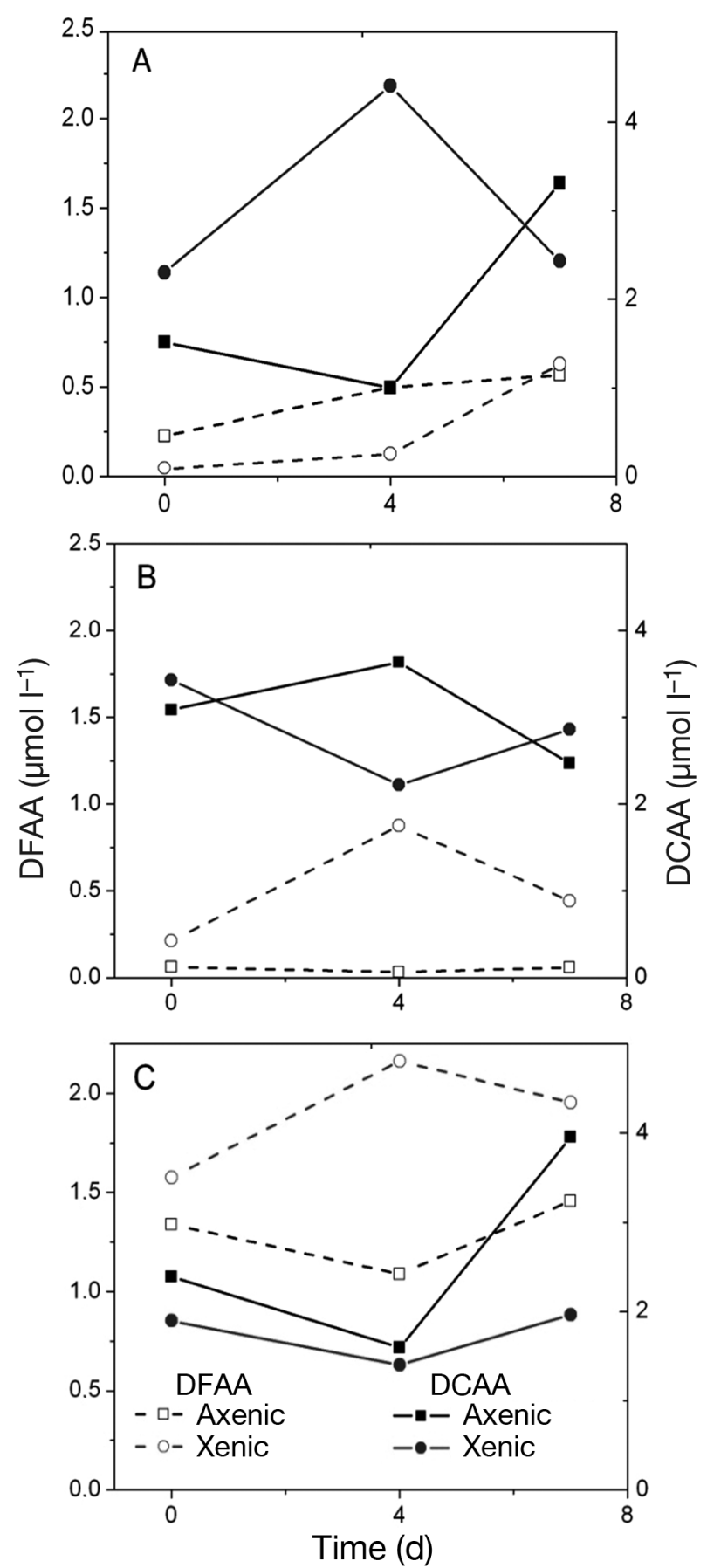

Fig. 5. Concentrations of dissolved free amino acids (DFAA) and dissolved combined amino acids (DCAA) in (A) nutrient-balanced ( $\mathrm{N}: \mathrm{P}=16)$, (B) nitrogen-depleted $(\mathrm{N}: \mathrm{P}=1)$, or (C) phosphorus-depleted treatments $(\mathrm{N}: \mathrm{P}=95)$ without (axenic) or with Marinobacter adhaerens HP15 (xenic)

depleted treatments, with similarly high values in the 2 axenic nutrient-depleted treatments and more than 2 orders of magnitude lower values in the xenic, nitrogen-depleted treatment (Table 3). 


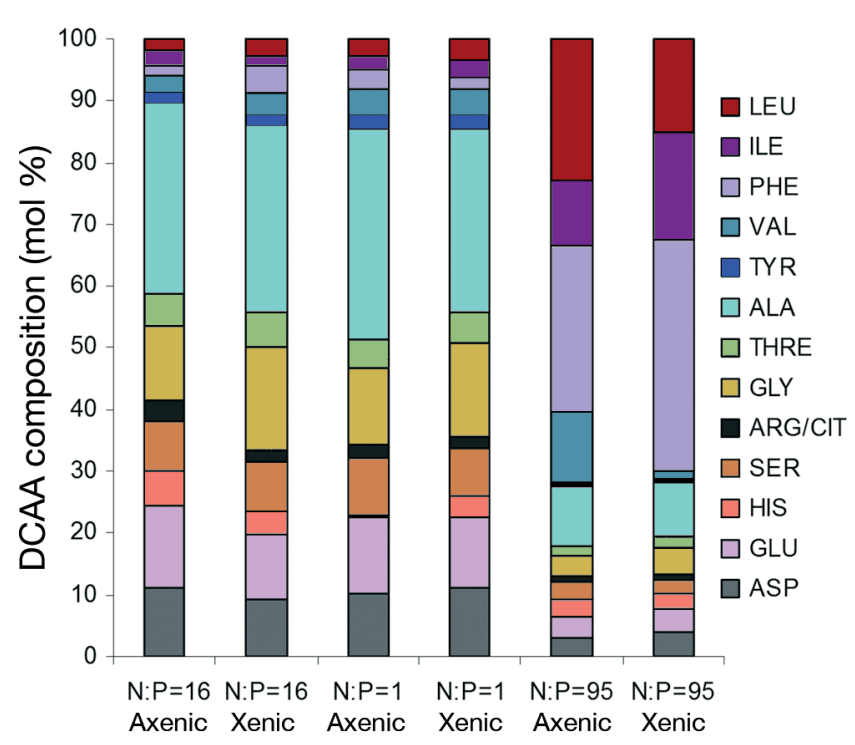

Fig. 6. Mol\% composition of dissolved combined amino acids (DCAA) from the 6 treatments after $7 \mathrm{~d}$ of incubation. Amino acids are ASP: aspartate; GLU: glutamate; HIS: histidine; SER: serine; GLY: glycine; THRE: threonine; ALA: alanine; TYR: tyrosine; VAL: valine; PHE: phenylalanine; ILE: isoleucine; LEU: leucine

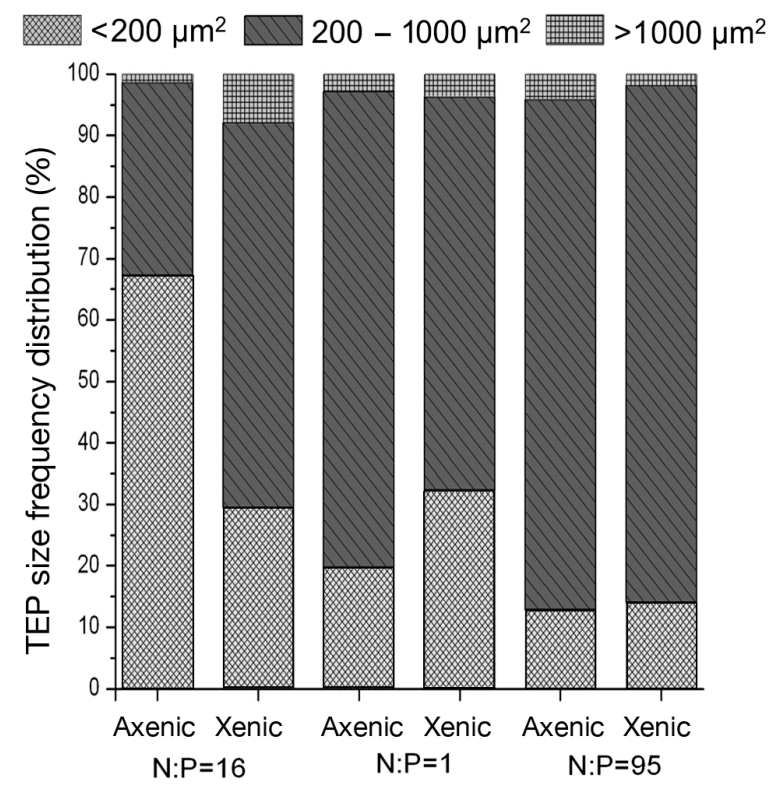

Fig. 7. Relative size distributions of transparent exopolymer particles (TEP) in the 6 treatments after $7 \mathrm{~d}$ of incubation partitioned into 3 size classes: $10-200 \mu^{2}, 200-1000 \mu^{2}$, and $>1000 \mu^{2}$

\section{Lectin-stainable exopolymers}

To gain better knowledge of the origin and nature of produced exopolymers, fluorescence-assisted staining of samples with FITC-ConA and TRITC-Bandeiraea was conducted, and lectin staining was visualized by
Table 3. Diatom normalized transparent polymer particle (TEP) concentration in the 6 treatments. Date are mean \pm SD

\begin{tabular}{|lccc|}
\hline & \multicolumn{3}{c|}{ TEP per diatom cell $\left(10^{4} \mu^{2}\right.$ cell $\left.^{-1}\right)$} \\
& $\mathrm{N}: \mathrm{P}=16$ & $\mathrm{~N}: \mathrm{P}=1$ & $\mathrm{~N}: \mathrm{P}=95$ \\
\hline & & & \\
Axenic & $8.0 \pm 0.14$ & $28 \pm 0.09$ & $26 \pm 0.28$ \\
Xenic & $16 \pm 0.34$ & $0.053 \pm 0.6$ & $38 \pm 0.51$ \\
\hline
\end{tabular}

CLSM. After $1 \mathrm{~d}$ of incubation (Fig. 8), ConA (green) was observed as a thin layer on diatom surfaces and also bound to free particles in the axenic, nitrogendepleted treatment only (Fig. 8C). Staining with TRITC-Bandeiraea did not yield signals in any of the treatments on Day 1 of the incubations.

After $7 \mathrm{~d}$ of incubation (Fig. 8), FITC-ConA-staining on diatom surfaces was visible in xenic, nutrientbalanced, and nitrogen-depleted treatments (Fig. 8H,J), as well as in both xenic and axenic phosphorusdepleted treatments (Fig. 8K,L) In contrast, Thalassiosira weissflogii cells did not reveal any FITCConA-stained cell surface bound signals in axenic, nutrient-balanced (Fig. 8G) and axenic, nitrogendepleted (Fig. 8J) treatments, indicating the absence of polymeric material with glycosidic residues. Free FITC-ConA-stainable material was found abundantly in both axenic and xenic, nitrogen-depleted treatments (Fig. 8I,J) as well as in the xenic nutrientbalanced treatment (Fig. 8H), but not in the other treatments. A strong lectin TRITC-Bandeiraea (yellow) signal overlapped with the FITC-ConA signal in the xenic, nutrient-balanced treatment (Fig. 8H), but was not seen in any of the other treatments. The appearance of TRITC-Bandeiraea in association with FITC-ConA suggests that the FITC-ConA-stained exopolymer had been either modified by bacterial activity or a secondary exopolymer had been released by the diatom in the presence of bacteria under nutrient-balanced conditions.

\section{DISCUSSION}

In the 6 treatments, the diatoms were grown under 3 different nutrient regimes in the presence or absence of a bacterial strain known to be associated with this diatom (Gärdes et a. 2011). The nutrient regimes differed in their N:P stoichiometry (Redfield stoichiometry versus nitrogen or phosphorus depletion), but also in effective nutrient availability during the experiment. Nitrogen and phosphorus remained available throughout the experiment in the 2 nutrient-balanced treatments, whereas nitrogen concen- 


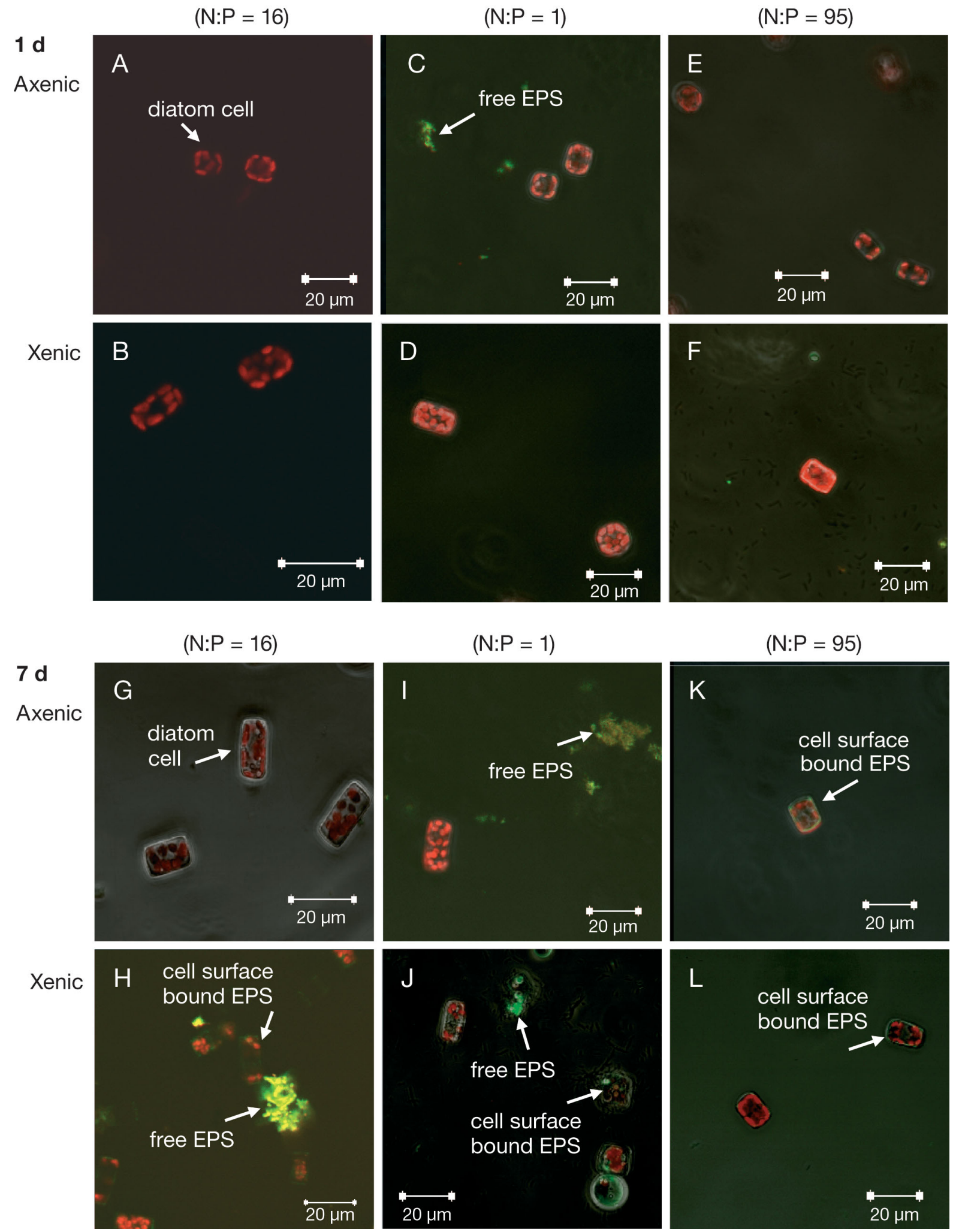

Fig. 8. Staining with FITC-ConA (green) and TRITC-Bandeira (yellow) after (A-F) $1 \mathrm{~d}$ and (G-L) 7d of incubation visualized with confocal laser scanning microscopy in $(A, B, G, H)$ nutrient-balanced $(N: P=16) ;(C, D, I, J)$ nitrogen-depleted $(N: P=1)(C)$ axenic and (D) xenic; and $(\mathrm{E}, \mathrm{F}, \mathrm{K}, \mathrm{L})$ phosphorus-depleted $(\mathrm{N}: \mathrm{P}=95)$ treatments. Red auto-fluorescence of chlorophyll is also visible. Arrows: examples of diatom cells, free exopolymers (EPS), and cell-surface-bound EPS 
tration dropped below $1 \mu \mathrm{M}$ in less than $4 \mathrm{~d}$ in both nitrogen-depleted treatments. In the phosphorusdepleted treatments, phosphate concentration after 4 d was below $1 \mu \mathrm{M}$ under axenic conditions, but remained at $\geq 2 \mu \mathrm{M}$ under xenic conditions. Phytoplankton growth in the xenic phosphorus-depleted treatment may have thus not been phosphorus-limited.

The results from the ANOVAs suggested that bacterial activity significantly impacted cell growth and the accumulation of different pools of carbon in nutrient-balanced conditions, but had little overall effect under nutrient-depleted conditions. Specifically, bacteria promoted diatom growth when grown under nutrient-balanced conditions, but had little effect under nutrient-depleted conditions. In this context, it should be noted that bacterial growth only occurred in the presence of diatom growth, and specifically benefited from optimal growth of the diatoms, suggesting a mutualistic relationship between diatoms and bacteria (Bell \& Mitchell 1972, Azam \& Ammerman 1984). It is likely that a trophic interplay between these organisms exists, more likely of a biotrophic than of a necrotrophic nature.

The DOC patterns observed in the xenic treatments of our experiment reflect the net result of active release or passive leakage of organic matter from diatoms as well as bacterial production, utilization, and modification of exudates. Marine bacteria release exoenzymes that hydrolyze complex DOC molecules, which may than be taken up by bacteria, supporting their growth (Azam \& Cho 1987, Martinez et al. 1996, Grossart et al. 2005, 2007). Under nutrientbalanced conditions, the growth of bacteria resulted in decreased DOC accumulation (200 $\mu \mathrm{M}$ difference) in the xenic compared to the axenic treatment. In both nutrient-depleted treatments, the accumulation of DOC concentration was similar in axenic and xenic treatments, suggesting that bacterial DOC utilization was small. Presumably, concentrations of inorganic nutrients, which are required for bacterial DOC utilization (Ducklow et al. 1986, Carlson \& Ducklow 1996, Stoderegger \& Herndl 1998, Thingstad et al. 2008) limited bacterial growth rate. However, bacterial cell numbers did increase in both nutrient-depleted treatments, albeit less than in the nutrient-balanced treatment. Since DOC release and consumption occur simultaneously, we cannot rule out that even in nutrient-depleted treatments bacteria stimulated exudation of organic carbon by Thalassiosira weissflogii while utilizing the additional DOC.

The most labile components of the marine DOC pool are DFAA and DCAA as well as DFCHO and
DCCOH (Pakulski \& Benner 1994, Weiss \& Simon 1999, Rosenstock \& Simon 2001). Pronounced differences in DCAA composition between treatments grown under nutrient-balanced or phosphorusdepleted conditions (irrespective of the presence of bacteria) suggested that the quality of algal-derived DOC, or at least the amino acid fraction of DOC, depended largely on the availability of phosphorus. These findings are consistent with previous studies (Myklestad \& Haug 1972, Staats et al. 2000, Meon \& Kirchman 2001, Granum et al. 2002), which demonstrated that quantity and quality of algal exudation depend on nutrient availability, through its effect on the physiological state of the algae. Bacterial activity also shapes amino acid concentration, e.g. via the release of enzymes such as alkaline phosphates (Hoppe et al. 1988, Ammerman \& Azam 1991, Smith et al. 1992). The highest DFAA and DCAA concentrations were indeed observed in xenic treatments under phosphorus-depleted conditions. High DFAA concentration may be the result of extensive DCAA hydrolysis, especially under nutrient-limited conditions. This notion is supported by the observation that in the second half of the experiment, DFAA concentrations increased while DCAA concentrations decreased in the presence of bacteria. Thus a tight coupling between protein hydrolysis and amino acid uptake can be assumed in our experiments, as described earlier (Hoppe et al. 1988).

Differences in carbohydrate (DCCHO) concentrations between nitrogen-depleted treatments and phosphorus-depleted or nutrient-balanced treatments imply that nitrogen depletion resulted in increased DCCHO exudation, but that this was not directly influenced by bacteria.

In our experimental model system, bacteria did not appear to drive DOC composition; rather nutrient availability — which affected exudation by diatoms appeared to control quantity and composition of the carbohydrates and amino acids in the water. Carbon is also partitioned between dissolved and particulate pools. Although the formation of TEP from dissolved precursors is largely abiotic (Passow 2000, Verdugo \& Santschi 2010), bacteria may contribute to TEP production (Mari \& Kiørboe 1996, Pedrotti et al. 2009).

In our experiments, bacterial activity resulted in increased TEP abundance and a shift towards larger TEP in the nutrient-balanced treatment, but had no significant effect in either of the nutrient-depleted treatments. Increase in larger TEP size and maximal cell-specific TEP concentration $\left(\mu \mathrm{m}^{2}\right.$ diatom $\left.^{-1}\right)$ occurred in phosphorus-depleted treatments regardless of the presence of bacteria and in the axenic nitrogen- 
depleted treatment. The measured TEP concentrations observed in the axenic nitrogen-depleted treatments were high; more than 2 orders of magnitude lower cell-specific TEP concentrations were observed in the xenic nitrogen-depleted treatment, suggesting that under nitrogen limitation, bacteria utilized TEP extensively. This is in contrast with in situ findings of increased TEP concentrations under nitrogen-limiting conditions (Mari \& Burd 1998) as well as with studies of TEP production in other algae cultures under nitrogen-limited conditions (Corzo et al. 2000, Staats et al. 2000, Beauvais et al. 2006).

Cell-surface-bound EPS and EPS fibrils released by the diatoms may act as TEP precursors and contribute to the TEP pool (Passow \& Alldredge 1994a, Zhou et al. 1998). One fraction might be lectinstainable deoxysugar-rich polysaccharides, which are known to be well correlated to cell stickiness (Waite et al. 1995) and TEP concentrations, and therefore important for aggregate formation (Mopper et al. 1995). Lectin staining revealed that exopolymers, both those associated with diatom surfaces and those that were free, were well developed in the xenic, nutrient-balanced treatment. In this treatment, bacterial activities may have led to the modification or de novo synthesis of additional polysaccharides which were not detected in nitrogen- or phosphorus-depleted treatments. We speculate that bacterial colonization of algal surfaces and the mutualistic interaction under nutrient-balanced conditions may lead to stimulation of excretion of different types of polysaccharides, which in turn may be important for TEP formation and stickiness. The lack of free stainable EPS material in phosphorus-depleted treatments is not in line with the observed high cell-specific TEP concentrations, which suggested that different polysaccharides were formed with different N:P stoichiometry non-detectable with the 2 lectins used in this experiment.

The results of this study demonstrated distinct effects of the diatom-associated bacterium Marinobacter adhaerens on (1) diatom growth and (2) algal exudation during nutrient-balanced growth conditions (but not during nutrient-depleted conditions). Nitrogen or phosphorus depletion had variable effects on algal exudation. While phosphorus-limited treatments differed in the quality and composition of DCAA, TEP size frequency and released polysaccharides, nitrogen-limited treatments showed quantitative differences in carbohydrates and cell-specific TEP concentrations. It is important to understand the factors governing the production of exudation products, because the quantity and quality of released
DOC and the formation of TEP have the potential to change the aggregation dynamics of diatoms (Alldredge et al. 1993, Passow 2002b, Bhaskar et al. 2005). The aggregation, and subsequent sedimentation, of particulate organic matter are key mechanisms for oceanic carbon sequestration, and also control marine biogeochemical cycles, as well as affecting the efficiency of the biological carbon pump (Fowler \& Knauer 1986, Jahnke 1996)

\section{CONCLUSIONS}

In our study, the interplay of the diatom-associated bacterium Marinobacter adhaerens and the algal model species Thalassiosira weissflogii depended on nutrient stoichiometry and availability. Based on our data, we hypothesize that phytoplankton exudation may have evolved as a mechanism to establish mutualism with bacteria, which may shift to commensalism when nutrients become limited.

In the field, bacterial and algal populations are far more complex than in our bilateral model system, and environmental conditions change continuously. Consequently, bacteria-algae interactions in situ are likely to be very dynamic. However, results obtained with our simplistic model system clearly identify nitrogen and phosphorus concentrations and their stoichiometry as important factors governing bacteria-diatom interactions. As the nutrient environment changes continuously, for example during the progression of phytoplankton blooms, the type of interaction between diatoms, their exudates, and bacteria is likely to change continuously. The very dynamic nature of these processes have to be considered and included in modeling studies to accurately predict carbon cycling in the ocean.

Acknowledgements. We thank the members of the Aquatic Microbial Ecology Group at IGB (Leibniz Institute of Freshwater Ecology and Inland Fisheries) and S. Seebah for technical assistance and fruitful discussions. This work was supported by the Deutsche Forschungsgemeinschaft (UL 169/6-1 and GR 1540-8/1-2) and by the National Science Foundation (NSF: OCE-0926711).

\section{LITERATURE CITED}

Alldredge AL, Passow U, Logan BE (1993) The abundance and significance of a class of large, transparent organic particles in the ocean. Deep-Sea Res I 40:1131-1140

- Ammerman JW, Azam F (1991) Bacterial 5 - nucleotidase activity in estuarine and coastal marine waters - characterization of enzyme activity. Limnol Oceanogr 36: $1427-1436$ 
Azam F, Ammerman JW (1984) Cycling of organic matter by bacterioplankton in pelagic marine ecosystems: microenvironmental considerations. In: Fasham MJR (ed) Flows of energy and materials in marine ecosystems. Plenum, New York, NY, p 345-360

Azam F, Cho BC (1987) Bacterial utilization of organic matter in the sea. Symposium of the Society for General Microbiology. 4.1. Ecology of microbial communities. Cambridge University Press, Cambridge, p 261-281

Azam F, Malfatti F (2007) Microbial structuring of marine ecosystems. Nat Rev Microbiol 5:782-791

Beauvais S, Pedrotti ML, Egge J, Iversen K, Marrase C (2006) Effects of turbulence on TEP dynamics under contrasting nutrient conditions: implications for aggregation and sedimentation processes. Mar Ecol Prog Ser 323: 47-57

Bell W, Mitchell R (1972) Chemotactic and growth responses of marine bacteria to algal extracellular products. Biol Bull (Woods Hole) 143:265-277

Bhaskar PV, Grossart HP, Bhosle NB, Simon M (2005) Production of macroaggregates from dissolved exopolymeric substances (EPS) of bacterial and diatom origin. FEMS Microbiol Ecol 53:255-264

Bidle KD, Azam F (1999) Accelerated dissolution of diatom silica by marine bacterial assemblages. Nature 397: 508-512

> Bruckner CG, Rehm C, Grossart HP, Kroth PG (2011) Growth and release of extracellular organic compounds by benthic diatoms depend on interactions with bacteria. Environ Microbiol 13:1052-1063

> Carlson CA, Ducklow HW (1996) Growth of bacterioplankton and consumption of dissolved organic carbon in the Sargasso Sea. Aquat Microb Ecol 10:69-85

Chin WC, Orellana MV, Verdugo P (1998) Spontaneous assembly of marine dissolved organic matter into polymer gels. Nature 391:568-572

Corzo A, Morillo JA, Rodriguez S (2000) Production of transparent exopolymer particles (TEP) in cultures of Chaetoceros calcitrans under nitrogen limitation. Aquat Microb Ecol 23:63-72

> Ducklow HW, Purdie DA, Williams PJL, Davies JM (1986) Bacterioplankton: a sink for carbon in a coastal marine plankton community. Science 232:865-867

Fowler SW, Knauer GA (1986) Role of large particles in the transport of elements and organic compounds through the oceanic water column. Prog Oceanogr 16:147-194

Gärdes A, Kaeppel E, Shehzad A, Seebah S and others (2010) Complete genome sequence of Marinobacter adhaerens type strain (HP15), a diatom-interacting marine microorganism. Stand Genomic Sci 3:97-107

Gärdes A, Iversen MH, Grossart HP, Passow U, Ullrich MS (2011) Diatom-associated bacteria are required for aggregation of Thalassiosira weissflogii. ISME J 5:436-445

Granum E, Kirkvold S, Myklestad SM (2002) Cellular and extracellular production of carbohydrates and amino acids by the marine diatom Skeletonema costatum: diel variations and effects of $\mathrm{N}$ depletion. Mar Ecol Prog Ser 242:83-94

Grossart HP (1999) Interactions between marine bacteria and axenic diatoms (Cylindrotheca fusiformis, Nitzschia laevis, and Thalassiosira weissflogii) incubated under various conditions in the lab. Aquat Microb Ecol 19:1-11

Grossart HP, Schlingloff A, Bernhard M, Simon M, Brinkhoff $\mathrm{T}$ (2004) Antagonistic activity of bacteria isolated from organic aggregates of the German Wadden Sea. FEMS
Microbiol Ecol 47:387-396

Grossart HP, Levold F, Allgaier M, Simon M, Brinkhoff T (2005) Marine diatom species harbour distinct bacterial communities. Environ Microbiol 7:860-873

> Grossart HP, Czub G, Simon M (2006) Algae-bacteria interactions and their effects on aggregation and organic matter flux in the sea. Environ Microbiol 8:1074-1084

> Grossart HP, Tang KW, Kiørboe T, Ploug H (2007) Comparison of cell-specific activity between free-living and attached bacteria using isolates and natural assemblages. FEMS Microbiol Lett 266:194-200

Guillard RRL (1975) Culture of phytoplankton for feeding marine invertebrates. In: Smith WL, Chanley MH (eds) Culture of marine invertebrate animals. Plenum Press, New York, NY, p 108-132

Hoppe HG, Kim SJ, Gocke K (1988) Microbial decomposition in aquatic environments-combined process of extracellular enzyme-activity and substrate uptake. Appl Environ Microb 54:784-790

Jahnke RA (1996) The global ocean flux of particulate organic carbon: aereal distribution and magnitude. Global Biogeochem Cycles 10:71-88

> Kaeppel EC, Gärdes A, Seebah S, Grossart HP, Ullrich MS (2012) Marinobacter adhaerens sp. nov., a particle associated bacteria isolated from the German Bight. Int J Syst Evol Microbiol 62:124-128

> Laspidou CS, Rittmann BE (2002) A unified theory for extracellular polymeric substances, soluble microbial products, and active and inert biomass. Water Res 36: 2711-2720

Liener I, Sharon N, Goldstein I (1986) The lectins: properties, functions and applications in biology and medicine. Academic Press, London

Logan BE, Passow U, Alldredge AL, Grossart HP, Simon M (1995) Rapid formation and sedimentation of large aggregates is predictable from coagulation rates (half-lives) of transparent exopolymer particles (TEP). Deep-Sea Res II 42:203-214

Lovdal T, Eichner C, Grossart HP, Carbonnel V, Chou L, Martin-Jezequel V, Thingstad TF (2008) Competition for inorganic and organic forms of nitrogen and phosphorus between phytoplankton and bacteria during an Emiliania huxleyi spring bloom. Biogeosciences 5:371-383

Magaletti E, Urbani R, Sist P, Ferrari CR, Cicero AM (2004) Abundance and chemical characterization of extracellular carbohydrates released by the marine diatom $C y$ lindrotheca fusiformis under N- and P-limitation. Eur J Phycol 39:133-142

Mari X, Burd A (1998) Seasonal size spectra of transparent exopolymeric particles (TEP) in a coastal sea and comparison with those predicted using coagulation theory. Mar Ecol Prog Ser 163:63-67

- Mari X, Kiørboe T (1996) Abundance, size distribution and bacterial colonization of transparent exopolymeric particles (TEP) during spring in the Kattegat. J Plankton Res 18:969-986

Martinez J, Smith DC, Steward GF, Azam F (1996) Variability in ectohydrolytic enzyme activities of pelagic marine bacteria and its significance for substrate processing in the sea. Aquat Microb Ecol 10:223-230

> Meon B, Kirchman DL (2001) Dynamics and molecular composition of dissolved organic material during experimental phytoplankton blooms. Mar Chem 75:185-199

Mopper K, Schultz CA, Chevolot L, Germain C, Revuelta R, Dawson R (1992) Determination of sugars in uncon- 
centrated seawater and other natural waters by liquidchromatography and pulsed amperometric detection. Environ Sci Technol 26:133-138

Mopper K, Zhou JA, Ramana KS, Passow U, Dam HG, Drapeau DT (1995) The role of surface-active carbohydrates in the flocculation of a diatom bloom in a mesocosm. Deep-Sea Res II 42:47-73

Myklestad (1974) Production of carbohydrates by marine planktonic diatoms. 1. Comparison of 9 different species in culture. J Exp Mar Biol Ecol 15:261-274

Myklestad S (1977) Production of carbohydrates by marine planktonic diatoms. 2. Influence of N-P ratio in growth medium on assimilation ratio, growth rate, and production of cellular and extracellular carbohydrates by Chaetoceros affinis var. willei (Gran) Hustedt and Skeletonema costatum (Grev.) Cleve. J Exp Mar Biol Ecol 29: 161-179

> Myklestad S, Haug A (1972) Production of carbohydrates by the marine diatom Chaetoceros affinis var. willei (Gran) Hustedt. I. Effect of the concentration of nutrients in the culture medium. J Exp Mar Biol Ecol 9:125-136

Obernosterer I, Herndl GJ (1995) Phytoplankton extracellular release and bacterial growth: dependence on the inorganic N:P ratio. Mar Ecol Prog Ser 116:247-257

Pakulski JD, Benner R (1994) Abundance and distribution of carbohydrates in the ocean. Limnol Oceanogr 39:930-940

Passow U (2000) Formation of transparent exopolymer particles, TEP, from dissolved precursor material. Mar Ecol Prog Ser 192:1-11

Passow U (2002a) Production of transparent exopolymer particles (TEP) by phyto- and bacterioplankton. Mar Ecol Prog Ser 236:1-12

$>$ Passow U (2002b) Transparent exopolymer particles (TEP) in aquatic environments. Prog Oceanogr 55:287-333

Passow U, Alldredge AL (1994a) Abiotic formation of transparent exopolymer particles (TEP) from polysaccharides excreted by phytoplankton. Abstr Pap Am Chem Soc 207:178

Passow U, Alldredge AL (1994b) Distribution, size and bacterial colonization of transparent exopolymer particles (TEP) in the ocean. Mar Ecol Prog Ser 113:185-198

Pedrotti ML, Beauvais S, Kerros ME, Iversen K, Peters F (2009) Bacterial colonization of transparent exopolymeric particles in mesocosms under different turbulence intensities and nutrient conditions. Aquat Microb Ecol 55: 301-312

Pierre G, Graber M, Rafiliposon B, Dupuy C, Orvain F, De Crignis M, Maugard T (2012) Biochemical composition and changes of extracellular polysaccharides (ECPS) produced during microphytobenthic biofilm development (Marennes-Oléron, France). Microb Ecol 63:157-169

Porter KG, Feig YS (1980) The use of DAPI for identifying and counting aquatic microflora. Limnol Oceanogr 25: 943-948

Rosenstock B, Simon M (1993) Use of dissolved combined and free amino acids by planktonic bacteria in Lake Constance. Limnol Oceanogr 38:1521-1531

Rosenstock B, Simon M (2001) Sources and sinks of dis-

Editorial responsibility: Matthias Seaman,

Oldendorf/Luhe, Germany solved free amino acids and protein in a large and deep mesotrophic lake. Limnol Oceanogr 46:644-654

Sapp M, Gerdts G, Wellinger M, Wichels A (2008) Consuming algal products: trophic interactions of bacteria and a diatom species determined by RNA stable isotope probing. Helgol Mar Res 62:283-287

> Smith DC, Simon M, Alldredge AL, Azam F (1992) Intense hydrolytic enzyme activity on marine aggregates and implications for rapid particle dissolution. Nature 359: 139-142

Smith DC, Steward GF, Long RA, Azam F (1995) Bacterial mediation of carbon fluxes during a diatom bloom in a mesocosm. Deep-Sea Res II 42:75-97

Sonnenschein EC, Gärdes A, Seebah S, Torres-Monroy I, Grossart HP, Ullrich MS (2011) Development of a genetic system for Marinobacter adhaerens HP15 involved in marine aggregate formation by interacting with diatom cells. J Microbiol Methods 87:176-183

Staats N, Stal LJ, Mur LR (2000) Exopolysaccharide production by the epipelic diatom Cylindrotheca closterium: effects of nutrient conditions. J Exp Mar Biol Ecol 249: $13-27$

> Stal LJ (2003) Microphytobenthos, their extracellular polymeric substances, and the morphogenesis of intertidal sediments. Geomicrobiol J 20:463-478

Stoderegger K, Herndl GJ (1998) Production and release of bacterial capsular material and its subsequent utilization by marine bacterioplankton. Limnol Oceanogr 43:877-884

Strickland JDH, Parsons TR (1972) A practical handbook of seawater analysis. Fish Res Board Can, Ottawa

Thingstad TF, Bellerby RGJ, Bratbak G, Borsheim KY and others (2008) Counterintuitive carbon-to-nutrient coupling in an Arctic pelagic ecosystem. Nature 455:387-390

Verdugo P, Santschi PH (2010) Polymer dynamics of DOC networks and gel formation in seawater. Deep-Sea Res II 57:1486-1493

Verdugo P, Alldredge AL, Azam F, Kirchman DL, Passow U, Santschi PH (2004) The oceanic gel phase: a bridge in the DOM-POM continuum. Mar Chem 92:67-85

> Waite AM, Olson RJ, Dan HG, Passow U (1995) Sugarcontaining compounds on the cell surfaces of marine diatoms measured using concanavalin A and flow cytometry. J Phycol 31:925-933

Weiss M, Simon M (1999) Consumption of labile dissolved organic matter by limnetic bacterioplankton: the relative significance of amino acids and carbohydrates. Aquat Microb Ecol 17:1-12

- Wigglesworth-Cooksey B, Cooksey KE (2005) Use of fluorophore-conjugated lectins to study cell-cell interactions in model marine biofilms. Appl Environ Microbiol 71: 428-435

Zhou J, Mopper K, Passow U (1998) The role of surfaceactive carbohydrates in the formation of transparent exopolymer particles by bubble adsorption of seawater. Limnol Oceanogr 43:1860-1871

ZoBell CE (1941) Studies on marine bacteria. I. The cultural requirements of heterotrophic aerobes. J Mar Res 4: $42-75$

Submitted: January 25, 2012; Accepted: June 21, 2012

Proofs received from author(s): July 27, 2012 